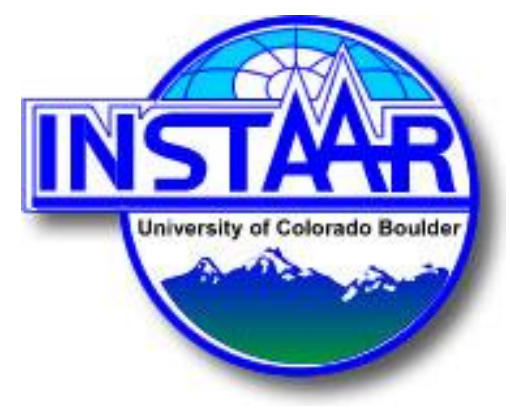

Response Behaviors of Svalbard Reindeer towards Humans and Humans Disguised as Polar Bears on Edgeøya

Author(s): Eigil Reimers and Sindre Eftest $\varnothing 1$

Source: Arctic, Antarctic, and Alpine Research, Vol. 44, No. 4 (November 2012), pp. 483-489 Published by: INSTAAR, University of Colorado

Stable URL: http://www.jstor.org/stable/23359630

Accessed: 21-10-2017 11:07 UTC

\title{
REFERENCES
}

Linked references are available on JSTOR for this article: http://www.jstor.org/stable/23359630?seq=1\&cid=pdf-reference\#references_tab_contents You may need to $\log$ in to JSTOR to access the linked references.

JSTOR is a not-for-profit service that helps scholars, researchers, and students discover, use, and build upon a wide range of content in a trusted digital archive. We use information technology and tools to increase productivity and facilitate new forms of scholarship. For more information about JSTOR, please contact support@jstor.org.

Your use of the JSTOR archive indicates your acceptance of the Terms \& Conditions of Use, available at http://about.jstor.org/terms

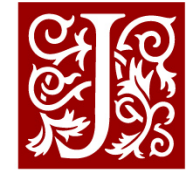

INSTAAR, University of Colorado is collaborating with JSTOR to digitize, preserve and extend access to Arctic, Antarctic, and Alpine Research 


\section{Response Behaviors of Svalbard Reindeer towards Humans and Humans Disguised as Polar Bears on Edgeøya}

\author{
Eigil Reimers* ${ }^{*}$ and \\ Sindre Eftest $\phi l^{*}$ \\ *Department of Biology, University of \\ Oslo, P.O. Box 1066 Blindern, 0316 \\ Oslo, Norway \\ $\dagger$ Corresponding author: \\ eigil.reimers@bio.uio.no
}

\begin{abstract}
Due to observed interactions between Svalbard reindeer (Rangifer tarandus platyrhynchus) and polar bears (Ursus maritimus) during field work on Edgeøya, Svalbard, we measured response distances for reindeer from a stalking polar bear and improvised five approaches from a person disguised as a polar bear for comparison with human encounters. The alert, flight initiation and escape distances were 1.6, 2.5 and 2.3 times longer, respectively, when Svalbard reindeer were encountered by a person disguised as a polar bear compared to a person in dark hiking gear. Population increase of polar bears on Svalbard and decrease in sea-ice cover in the Arctic region during summer probably results in more frequent interactions with reindeer on the archipelago. Similar reindeer response behavior from encounters with a polar bear and persons disguised as polar bears indicate a predator-prey relationship between the two species on Edgeøya.
\end{abstract}

\section{Introduction}

The insular Svalbard reindeer (Rangifer tarandus platyrhynchus Vrolik, 1829) maintain the northernmost populations of Rangifer, inhabiting an environment without large grazing competitors and parasitizing insects. Besides rare polar bear (Ursus maritimus Phipps, 1774) predator incidences (Derocher et al., 2000) and few killings of newborn calves by Arctic fox (Alopex lagopus) (Tyler, 1986), Rangifer predators like wolf (Canis lupus), wolverine (Gulo gulo), lynx (Lynx lynx), brown bear (Ursus arctos), or golden eagle (Aquila chrysaetos) are absent from the Svalbard reindeer's natural habitat. This situation has prevailed for at least 4000 years (Van der Knaap, 1986; Tyler and Øritsland, 1989). Contrary to Rangifer subspecies elsewhere and probably as an adaptation to the absence of predators, Svalbard reindeer live individually or in small groups (Alendal and Byrkjedal, 1976; Alendal et al., 1979), are seasonally sedentary (Tyler and Øritsland, 1989), and do not have the nomadic behavior known from other Rangifer subspecies. Gregariousness is commonly recognized as a way to escape predation and in the presence of predators, Rangifer subspecies in southern Norway, Russia, and North America group together, frequently counting several thousand individuals (e.g. Bergerud, 1974; Skogland, 1989; Syroechkovskii, 1995).

In a comparative study of vigilance and fright behavior of wild reindeer in southern Norway (Reimers et al., 2012) and Svalbard (Reimers et al., 2011), we found Svalbard reindeer to be less vigilant than mainland wild reindeer, but the differences were surprisingly small. Several studies have documented effects of relaxed selection on antipredator behavior in mammals, but at present show no consistency regarding the speed at which preydiscriminative abilities are lost (Caro, 2005). For example, Byers (1997) noted that antipredator behavior in pronghorns (Antilocapra americana), apparently designed to evade capture by extinct predators, has persisted since the last ice age. In contrast, Berger (1998) uncovered a rapid reduction in predator recognition abilities in North American ungulates isolated from predators for just tens of years. Despite the poor recognition skills of predator-naïve prey, wild animals learn about predators rapidly. Although moose (Alces alces) that had been unfamiliar with dangerous predators for as few as 50 to 130 years were highly vulnerable to initial encounters, behavioral adjustment to reduce predation transpired within a single generation (Berger et al., 2001).

Last week of our field work on Edgeøya, Svalbard in July/ August 2006 (Reimers et al., 2011, 2012), we witnessed a polar bear stalk a group of four reindeer in our study area on Edgeøya (Fig. 1). Earlier, we had observed polar bears on 5 occasions and recorded fresh polar bear tracks on Grunnlinjesletta, along the river Plura and in the inner part of the valley Plurdalen ca. $13 \mathrm{~km}$ from the coastline. In the evening of 4 August, a group of 9 reindeer ( 2 males, 5 females, and 2 calves) were observed grazing in a small side valley in the inner part of Plurdalen. Two days later, a polar bear was lying on the same grazing spot and reindeer were absent from the area. At this time, we had 50 recordings of reindeer responses towards persons approaching them and decided to improvise and disguised a person in white clothing, including a white mask, to simulate polar bear approaches, hereafter designated "polar bear" or "polar bear disguise"' (Fig. 2). Since reindeer on Edgeøya have been protected from human hunting since 1925, we assumed that the reindeer would display stronger behavioral responses from encounters with polar bears compared to humans. If so, we would expect longer response distances when reindeer were approached by a human disguised as a polar bear compared to when reindeer were approached by human dressed in dark clothing.

\section{Study Area}

The island Edgeøya (ca. $5150 \mathrm{~km}^{2}$ ), a nature reserve and part of the Svalbard archipelago (Fig. 1), is characterized by glaciers, 


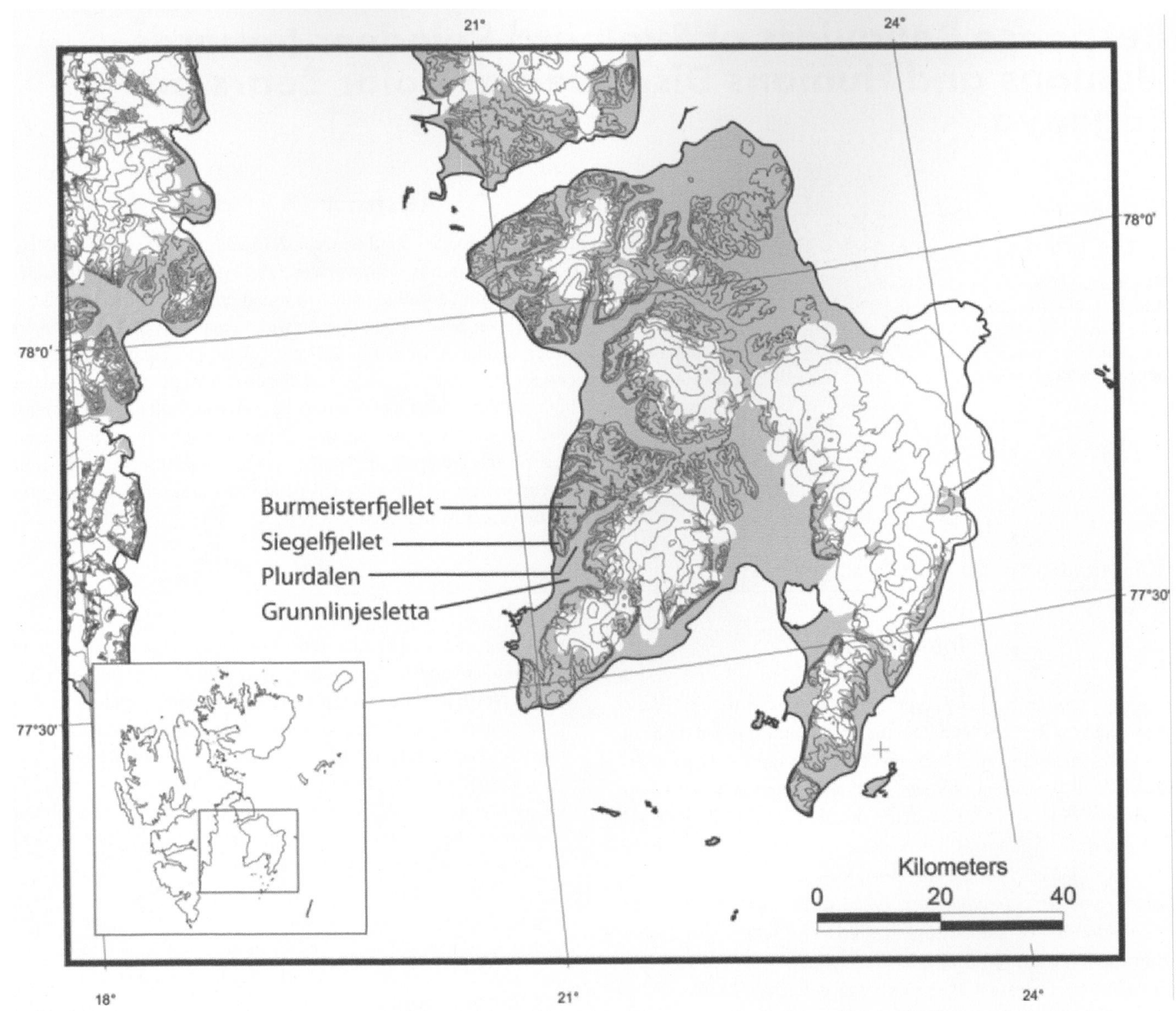

FIGURE 1. The study area: Plurdalen valley, Siegelfjellet, Burmeisterfjellet, and Grunnlinjesletta on Edgeøya, Svalbard, in July-August in 2006.

wide valleys, plateaus, and coastal plains. In the summer (June-September), reindeer are found in the valleys, coastal plains, and to some extent on the plateaus. Strict environmental regulations prevent tourist activities on the island and hence counteract habituation of reindeer to humans as reported elsewhere in Svalbard (Adventdalen) (Reimers et al., 2011). The present total reindeer summer population in Edgeøya is unknown, but was estimated at $1730 \pm 451$ (SD) for the period 1969-1996 (Øritsland, 1998). The study area was surveyed, and the number of reindeer was estimated at 181 animals in 2006, down from 227 animals in 1976 (Reimers, 2012).

After the international harvest ban in 1973, the population of polar bears in the Svalbard archipelago has increased and was estimated at approximately 2650 animals, half of which probably reproduce in the Svalbard area (Aars et al., 2009). Edgeøya is an important polar bear denning area (Larsen, 1985).

\section{Material and Methods}

\section{FRIGHT AND FLIGHT RESPONSES}

Flight initiation distance is the distance at which an animal begins to flee from an approaching predator (Ydenberg and Dill, 1986). Because it is relatively simple to systematically approach animals until they flee, it is an excellent metric with which to quantify an individual's fearfulness in various circumstances and is extensively used (Tarlow and Blumstein, 2007).

Behavioral responses were collected in Plurdalen, Grunnlinjesletta, Siegelfjellet and Burmeisterfjellet (Fig. 1) under snow-free conditions, during "daylight hours" between 0900 and 2400 in July and August 2006 by a single observer on foot. During 67 encounters, the observer dressed in dark hiking clothing and in 5 encounters in a "polar bear disguise" and moving in a forward leaning amble posture (Fig. 2). The observer measured response distances between the reindeer and the approacher and the resultant 

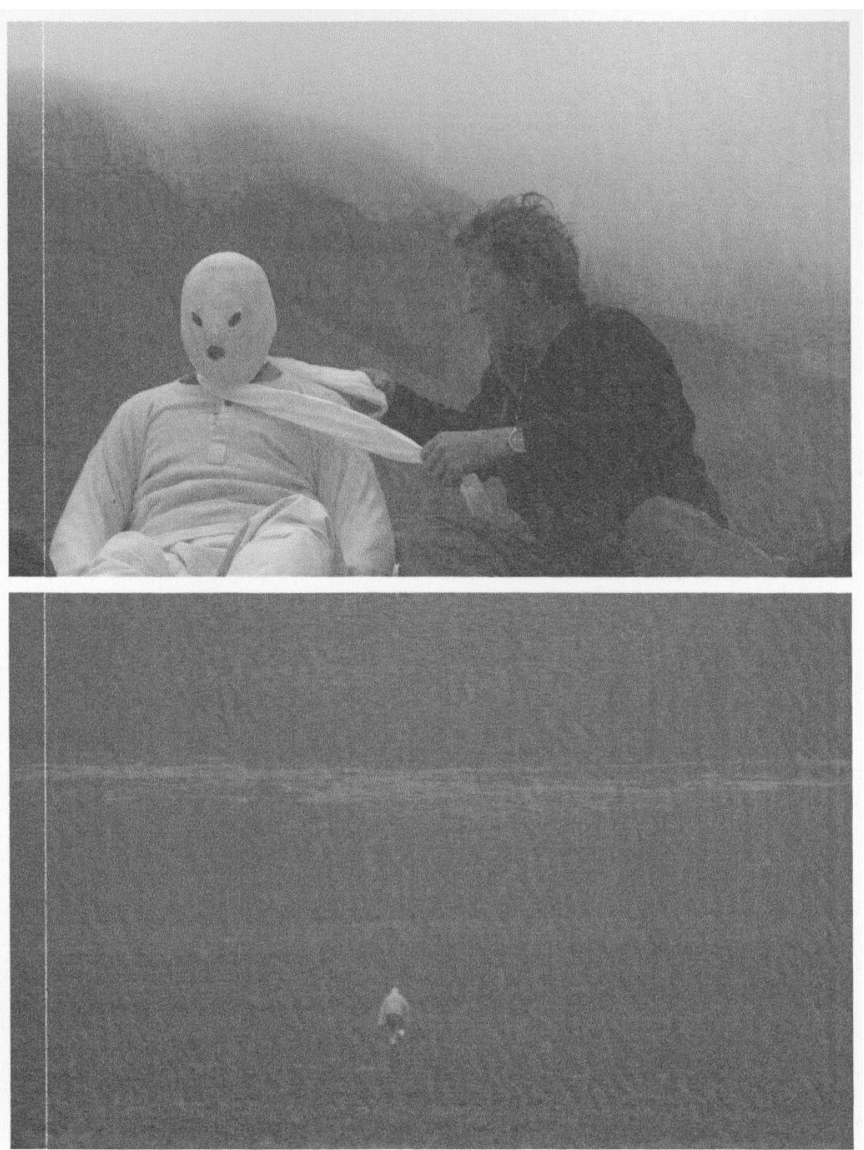

FIGURE 2. Lead author disguised as a polar bear approaching a group of Svalbard reindeer. Limited supplies of white clothing left the back of the observer uncovered. Photos by M. Kardel.

displacement distance by the reindeer after taking flight. All response distances were measured with laser monoculars (Leica Rangemaster 1200 Scan; $1 \mathrm{~m}$ accuracy at 1000-1200 m).

We used wildlife response distance terminology and methodology recommended by Taylor and Knight (2003) modified for our study by Reimers et al. (2011):

(1) Start distance: the distance between the approacher and the individual reindeer (or the closest animal if we encountered a group) before the start of a disturbance.

(2) Sight distance: the distance between the approacher and the closest animal when animals in the group displayed an alerted behavior directed at the approacher.

(3) Alert distance: the distance when the reindeer exhibited an increased alert response by grouping together or individuals urinating with one hind leg extended outward at an exaggerated angle, while staring at the approacher.

(4) Flight initiation distance: the distance from the approacher to the reindeer when the reindeer initially took flight.

(5) Escape distance: the shortest straight-line distance from where the reindeer took flight in response to the approacher to where the reindeer resumed grazing or bedded down.

Upon location of individuals or groups, 6 parameters were recorded: group size; group composition (mixed, yearlings and older of both sexes; males, yearlings and older; female(s) with calf at foot); dominant activity of the group when first sighted (lying or grazing); wind direction relative to the observer (tail wind or into the wind including crossways to the wind); topography of the surrounding area (level or rugged) and direction of the encounter (downhill, flat, or uphill).

The approacher measured the start distance and used a direct approach method (Reimers et al., 2011): advancing directly towards the animal or estimated center of the group at a constant speed $(\approx$ $4 \mathrm{~km} \mathrm{~h}^{-1}$ ) with three stops ( $\leq 6 \mathrm{~s}$ ) to measure the additional response distances (sight, alert, and flight initiation). The observer continued to approach the animal(s) on all occasions until reaching the position where the reindeer were located at the start of the disturbance for measurement of the escape distance from this point. All measurements were made from the position of the approacher to the closest animal in a group.

\section{STATISTICAL METHODS}

Reindeer were probably repeatedly approached during the field period but not on the same day, except the day when a group of 4 reindeer were approached first by a polar bear and again later by a person in "polar bear disguise."

Start, sight, alert, flight initiation, and escape distances were analyzed with linear models (LM) using statistical software $\mathrm{R}$ (http://www.r-project.org). Due to strongly imbalanced data, we reduced the encounters made by a person $(N=67)$ to include only mixed groups and individuals or groups of either females or males $(N=56)$, excluding females with calves at foot. Next, we included only fixed effects that were the same as when we approached in disguise (grazing animals, level terrain, head wind, and downhill or level encounters; $N=11$ ). The model fixed effects included approacher (person or "polar bear'), start distance in the sight model, and sight distance in the alert and flight initiation models (both centered at their means) (Table 1). To facilitate interpretation of the disturber on the four vigilance measures, we present predicted response values for encounters by person and "polar bear" (Fig. 3), which also show response distances in the total sample excluding females with calves $(N=56)$.

As a measure of effect size for the different treatments (persons vs. "polar bears"), we calculated d-scores (Cohen's effect size) for the different distances, subtracting the mean of the control group (person) from the mean of the experimental group ("polar bear") and dividing by the pooled standard deviation (Cohen, 1988).

\section{Results}

A person dressed in dark hiking gear approached individuals or small groups of reindeer $(\leq 11$; median $=2) 11$ times, and was disguised as a "polar bear" 5 times during July and August 2006 (Appendix Table A1). The response distances for alert, flight initiation, and escape were $1.6(2.0), 2.5$ (3.2), and 2.3 (4.0) times longer, respectively, when Svalbard reindeer were approached by a person in "polar bear disguise"' compared to a person in dark hiking gear. (Numbers in parentheses relate to person sample size $[N=56]$ ).

Start distance was longer (673 vs. 374 m [median 480 vs. 393 $\mathrm{m}]$ ) when reindeer were approached by a "polar bear" compared to a person in dark hiking clothing (Table 1). Start distance did not influence sight distance, which did not differ between the two 
TABLE 1

Summary of the linear models for predicting start, sight, alert, flight initiation, and escape distances of Svalbard reindeer groups disturbed by an approaching person $(N=11)$ or person disguised as polar bear $(N=5)$ in Edgeøya, Svalbard, in July-August 2006 . Reference levels for approacher is person disguised as a polar bear. Fixed effect values for start distance and sight distance were centered around the mean.

\begin{tabular}{|c|c|c|c|c|}
\hline Measurement & Estimate & SE & $t$-value & $P$-value \\
\hline Start distance $(m)$ Intercept & 673 & 91 & 7.36 & $<0.001$ \\
\hline Approacher (person vs. polar bear) & -299 & 110 & -2.71 & 0.017 \\
\hline \multicolumn{5}{|l|}{ Sight distance $(\mathrm{m})$} \\
\hline Intercept & 254 & 49 & 5.14 & $<0.001$ \\
\hline Start distance & 0 & 0 & 1.31 & 0.214 \\
\hline Approacher (person vs. polar bear) & -6 & 63 & -0.09 & 0.928 \\
\hline \multicolumn{5}{|l|}{ Alert distance $(\mathrm{m})$} \\
\hline Intercept & 220 & 26 & 8.60 & $<0.001$ \\
\hline Sight distance & 0 & 0 & 2.54 & 0.027 \\
\hline Approacher (person vs. polar bear) & -83 & 32 & -2.55 & 0.027 \\
\hline \multicolumn{5}{|l|}{ Flight initiation distance $(\mathrm{m})$} \\
\hline Intercept & 231 & 19 & 12.11 & $<0.001$ \\
\hline Sight distance & 0 & 0 & 1.27 & 0.230 \\
\hline Approacher (person vs. polar bear) & -139 & 24 & -5.76 & $<0.001$ \\
\hline \multicolumn{5}{|l|}{ Escape distance (m) } \\
\hline Intercept & 366 & 61 & 5.96 & $<0.001$ \\
\hline Approacher (person vs. polar bear) & -210 & 74 & -2.83 & 0.013 \\
\hline
\end{tabular}

approaches: $254 \mathrm{~m}$ (95\% CI: 156 to $352 \mathrm{~m})$ for "polar bears" vs. $248 \mathrm{~m}$ (95\% CI: 122 to $374 \mathrm{~m}$ ) for person in dark hiking gear (Figure 3, Table 1). Although not significant, the sight distances appear to be longer when reindeer were approached by a "polar bear" than when approached by a person in dark clothing (see both person samples in Fig. 3). Lack of significance most probably relates to small "polar bear" sample size.

Reindeer became alert at $220 \mathrm{~m}$ (95\% CI: 168 to $272 \mathrm{~m}$ ) and initiated flight at $231 \mathrm{~m}$ ( $95 \% \mathrm{CI}: 193$ to $269 \mathrm{~m}$ ) when they were

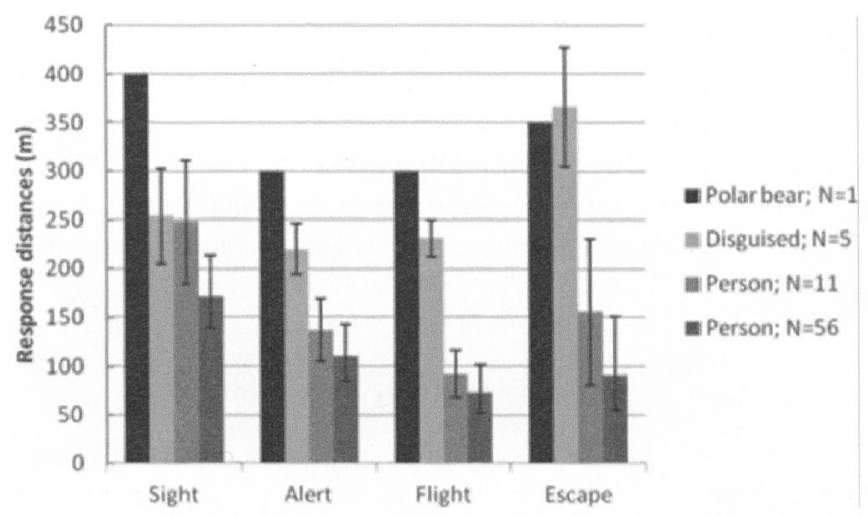

FIGURE 3. Predicted values ( \pm SE) of sight, alert, flight initiation, and escape distances of Svalbard reindeer groups disturbed by an approaching person or person disguised as a polar bear $(N=5)$ in Edgeøya, Svalbard, in July-August 2006. Person I denotes 11 encounters where model fixed effects (herd structure, terrain, wind, etc.) were similar to those when reindeer were encountered by a person in polar bear disguise. Person II denotes all person encounters excluding those of females with calf at foot. Polar bear denotes an approach by a single polar bear towards a mixed group of 4 reindeer (three females and one male). Polar bear response distances were estimated from GPS positions and maps. approached by a "polar bear" compared to $137 \mathrm{~m}$ (95\% CI: 73 to $201 \mathrm{~m})$ and $92 \mathrm{~m}$ (95\% CI: 44 to $140 \mathrm{~m})$, respectively, when approached by a person (Fig. 3, Table 1).

Escape distance was $366 \mathrm{~m}$ (95\% CI: 244 to $488 \mathrm{~m})$ when approached by the "polar bear" and $156 \mathrm{~m}$ (95\% CI: 8 to $304 \mathrm{~m})$ by a person. The furthest distance for an escape response was 455 $\mathrm{m}$ (median $=358 \mathrm{~m})$ when approached by a "polar bear" and $460 \mathrm{~m}$ (median $=105 \mathrm{~m}$ ) by a person.

A d-score as a measure of effect size for the different treatments (persons vs. " polar bears) were: start: 1.22 , sight: 0.56 , alert: 1.29 , flight initiation: 1.76 and escape distance: 1.26 , which translates into a median effect for sight distance and a large effect for the other distances (Ellis, 2010).

On one occasion, we observed a polar bear approaching a group of 4 reindeer into the wind from a start position of ca. 1500 $\mathrm{m}$. The reindeer discovered the bear at approximately $400 \mathrm{~m}$, became alert and initiated running/flight simultaneously at ca. 300 $\mathrm{m}$. They slowed down after ca. $350 \mathrm{~m}$ and watched the bear at a closest distance of approximately $250 \mathrm{~m}$ (equaling an escape distance of ca. $350 \mathrm{~m}$ ) as the bear had changed direction towards another small group of grazing reindeer. This second group was approached as the polar bear made use of ridges and narrow depressions, apparently undetected by the reindeer. At a point where no further hidden approach was possible, the bear laid down head pointing towards the animals. It remained there when we retreated to base camp after approximately one hour. The bear did not change its slow moving speed during the two approaches.

\section{Discussion}

Alert, flight initiation, and escape distances were 1.6, 2.5, and 2.3 times longer, respectively, when Svalbard reindeer were encountered by a person in "polar bear disguise" compared to a 
person in dark hiking gear. It is reasonable to assume that contrasting white color facilitated a longer sight distance than when approaching in dark gear, which is further enhanced in the larger sample $(N=56)$ and less so in the small sample $(N=11)$. Apart from sight distance, the two samples $(N=11$ and $N=56)$ did not predict the response distances differently although the larger sample tended to give somewhat shorter response distances (Fig. 3). As sight distance was correlated to neither flight initiation nor escape distance (Reimers et al., 2011), it is unlikely that visibility (white color vs. dark clothing) in itself should cause the longer fright and flight responses for the "polar bear" encounters unless the reindeer associated the appearance of the approaching white object with a threat, i.e. a predator. Even if our sample size is small, our results support an experience-dependant escape response that is adjusted to the level of potential predation risk, and not a response to a difference in visibility of the approaching object.

The way in which a population's anti-predator behavior is modified depends on its underlying developmental mechanisms in terms of both heritable predisposition (Riechert and Hedrick, 1990) as well as experience (Berger et al., 2001; Blumstein, 2004). Deecke et al (2002) found that harbor seals (Phoca vitulina) are capable of complex discrimination of different stimuli and that they may modify their predator image by selectively habituating only to harmless stimuli. They concluded that fear in seals is focused on local threats by learning and experience. The predator recognition may be olfactory, acoustic, and visual (Blumstein et al., 2000; Deecke et al., 2002; Webb et al., 2010; Kappel et al., 2011). Since there were no olfactory or acoustic stimuli in our study (head wind and no noise from the observer apart from normal walking noise during all approaches), predator recognition must have been associated with the visual image of the encountering object. Deecke et al (2002) observations are relevant in this context. They found that seals responded strongly towards both meateating killer whales and unfamiliar fish-eating killer whales, but not to local familiar fish-eating killer whales.

Although one observation of a polar bear approach $(N=1)$ provides little supporting evidence, it does not contradict the "polar bear disguise", response distances. This one encounter indicates that Svalbard reindeer indeed perceive polar bears as a predator. This is supported by Derocher et al. (2000) who in 1983-1999 (March-April) collected observations of seven predation events and six instances of scavenging of Svalbard reindeer by polar bears. Furthermore, in two recent newspaper articles, Hovelsrud (2009) and Sandal (2008) reported the killing of two reindeer males by polar bears in late spring (1991) and September (2008). Both males were apparently killed as a result of an ambush attack or a successful stalk. Also; Brook and Richardson (2002) reported that a polar bear was observed stalking and chasing caribou in western Hudson Bay in July. Even if these incidences are rare events, they show that polar bear may predate reindeer in all seasons, and thus lend support to a predator-prey relationship between the two species.

Experience-dependant behavior may be lost after the first generation in the absence of predators, while more "hard-wired" antipredator behavior may persist for thousands of years following isolation from predators (Byers, 1997; Coss, 1999). On the other hand, experience-dependant behavior may be quickly restored the first time individuals encounter predators (Brown et al., 1997). In accordance with this, we found a 2.2 times higher vigilance rate displayed by reindeer in Edge øya with a dense polar bear population compared to reindeer in Nordenskiöld Land with fewer polar bears (Reimers et al., 2011). However, Svalbard reindeer maintain small group size (average and median 2.9 and 2 animals, respectively) both on Edgeøya and in Nordenskiöld Land (Reimers et al. 2011). Maintenance of small group size is not expected if reindeer were exposed to strong predation pressure (see review by Caro, 2005, Table 4.4).

According to a recent summary report from the IUCN Polar Bear Specialist Group, there was likely an increase in the Barents Sea polar bear subpopulation from 1973 until recently (IUCN, 2010). Also, the sea-ice cover in the arctic region during summer has decreased (Singarayer et al., 2006) and is expected to continue decreasing in the years to come (Zhang and Walsh, 2006). This has caused an increase, and will probably continue influencing an increase in the amount of time individual polar bears spend on land (Derocher et al., 2004; Schliebe et al., 2008; Gleason and Rode, 2009). As a result, polar bears and reindeer are together for longer periods, a situation in which interactions between them could occur more frequently (Derocher et al., 2000). Nevertheless, we do not anticipate short-term effects on reindeer other than temporary and local changes in distribution and behavior (Reimers, 2012). The possibility for behavioral changes of both reindeer and polar bears in response to future increased interactions calls for a follow up study.

\section{Acknowledgments}

We thank the Governor on Svalbard for the necessary landing allowances on Edgeøya, The Norwegian Polar Institute for rent of necessary field equipment, M. Kardel and K. Reimers Kardel for field assistance, D. T. Alemu for statistical support, T. Severinsen for technical support, and J. E. Colman for linguistic support. Financial support was provided from The Norwegian Science Foundation, The Norwegian Polar Institute, and Framkomiteens Polarfond. A special thank to C. Bonenfant, V. B. Meyer-Rochow, S. C. Amstrup, and D. T. Blumstein for their constructive criticism of a previous version of the manuscript.

\section{References Cited}

Aars, J., Andersen, M., Belikov, S., Boltunov, A., Buckland, S. T., Marques, T. A., and Wiig, Ø., 2009: Estimating the Barents Sea polar bear subpopulation size. Marine Mammal Science, 25: 35-52.

Alendal, E., and Byrkjedal, I., 1976: Population size and reproduction of the reindeer (Rangifer tarandus platyrhynchus) on Nordenskiöld Land, Svalbard. Norsk Polarinstitutt Årbok, 1974: 139-152.

Alendal, E., de Bie, S., and van Wieren, S. E., 1979: Size and composition of the wild reindeer (Rangifer tarandus platyrhynchus) population in the Southeast Svalbard Nature Reserve. Holarctic Ecology, 2: 101-107.

Berger, J., 1998: Future prey: some consequences of the loss and restoration of large mammalian carnivores on prey. In Caro, T. (ed.), Behavioral Ecology and Conservation Biology. New York: Oxford University Press, 80-100.

Berger, J., Swenson, J. E., and Persson, I. L., 2001: Recolonizing carnivores and native prey: conservation lessons from Pleistocene extinctions. Science, 291: 1036-1039.

Bergerud, A. T., 1974: The role of the environment in the aggregation, 
movement and disturbance behavior of caribou. In Geist, V., and Walther, F. (eds.), The Behavior of Ungulates and Its Relation to Management. Morges, Switzerland: IUCN New Series Publications, 522-584.

Blumstein, D. T., 2004: A test of the multi-predator hypothesis: rapid loss of antipredator behavior after 130 years of isolation. Ethology, 110: 919-934.

Blumstein, D. T., Daniel, J. C., Griffin, A. S., and Evans, C. S., 2000: Insular tammar wallabies (Macropus eugenii). Behavioral Ecology, 11: 528-535.

Brook, R. K., and Richardson, E. S., 2002: Observations of polar bear predatory behaviour toward caribou. Arctic, 55: 193-196.

Brown, G. E., Chivers, D. P., and Smith, R. J. F., 1997: Differential learning rates of chemical versus visual cues of a northern pike by fathead minnows in a natural habitat. Environmental Biology of Fishes, 49: 89-96.

Byers, J. A., 1997: American Pronghorn: Social Adaptations and the Ghosts of Predators Past. Chicago: Chicago University Press.

Caro, T., 2005: Antipredator Defenses in Birds and Mammals. Chicago: Chicago University Press.

Cohen, J., 1988: Statistical Power Analysis for the Behavioral Sciences. Second edition. London: Lawrence Erlbaum Associates.

Coss, R. G., 1999: Effects of relaxed natural selection on the evolution of behavior. In Foster, S. A., and Endler, J. A. (eds.), Geographic Variation in Behavior: Perspectives on Evolutionary Mechanisms. Oxford: Oxford University Press, 180-208.

Deecke, V. B., Slater, P. J. B., and Ford, J. K. B., 2002: Selective habituation shapes acoustic predator recognition in harbour seals Nature, 420: 171-173.

Derocher, A. E., Wiig, O., and Bangjord, G., 2000: Predation of Svalbard reindeer by polar bears. Polar Biology, 23: 675-678.

Derocher, A. E., Lunn, N. J., and Stirling, I., 2004: Polar bears in a warming climate. Integrative and Comparative Biology, 44: $163-176$.

Ellis, P. D., 2010: The Essential Guide to Effect Sizes: an Introduction to Statistical Power, Meta-Analysis and the Interpretation of Research Results. Cambridge: Cambridge University Press.

Gleason, J. S., and Rode, K. D., 2009: Polar bear distribution and habitat association reflect long-term changes in fall sea ice conditions in the Alaskan Beaufort Sea. Arctic, 62: 405-417.

Hovelsrud, K. R., 2009: Isbjørn som dreper reinsdyr. Svalbardposten, 2: 20 (in Norwegian).

IUCN, 2010: Summary of polar bear population status per 2010. Copenhagen: Report from the IUCN Polar Bear Specialist Group.

Kappel, P., Hohenbrink, S., and Radespiel, U., 2011: Experimental evidence for olfactory predator recognition in wild mouse lemurs. American Journal of Primatology, 73: 928-938.

Larsen, T., 1985: Polar bear denning and cub production in Svalbard, Norway. Journal of Wildlife Management, 49: 320-326.

Øritsland, N. A., 1998: Reindeer population size and trend on Edgeøya Svalbard. Polar Research, 17: 101-105.
Reimers, E., 2012: Svalbard reindeer population size and trends in four subareas in Edgeøya. Polar Research, 31: http://dx.doi.org/10.3402/ polar.v31i0.11089.

Reimers, E., Lund, S., and Ergon, T., 2011: Vigilance and fright behaviour in the insular Svalbard reindeer. Canadian Journal of Zoology, 89: 753-764.

Reimers, E., Røed, K. H., and Colman, J. E., 2012: Persistence of vigilance and flight response behaviour in wild reindeer with varying domestic ancestry. Journal of Evolutionary Biology, 25: 1543-1554.

Riechert, S. E., and Hedrick, A. V., 1990: Levels of predation and genetically based anti-predator behaviour in the spider, Agenolopsis aperta. Animal Behaviour, 40: 679-687.

Sandal, T., 2008: Blant rein og bjørn. Svalbardposten, 49: 21 (in Norwegian).

Schliebe, S., Rode, K. D., Gleason, J. S., Wilder, J., Proffitt, K., Evans, T. J., and Miller, S., 2008: Effects of sea ice extent and food availability on spatial and temporal distribution of polar bears during the fallopen water period in the southern Beaufort Sea. Polar Biology, 31 : 999-1010.

Singarayer, J. S., Bamber, J. L., and Valdes, P. J., 2006: Twenty-firstcentury climate impacts from a declining Arctic Sea ice cover. Journal of Climate, 19: 1109-1125.

Skogland, T., 1989: Comparative social organization of wild reindeer in relation to food, mates and predator avoidance. Advances in Ethology, 29: 3-74.

Syroechkovskii, E. E., 1995: Wild Reindeer. Washington: Smithsonian Institution Libraries.

Tarlow, E. M., and Blumstein, D. T., 2007: Evaluating methods to quantify anthropogenic stressors on wild animals. Applied Animal Behaviour Science, 102: 429-451.

Taylor, A. R., and Knight, R. L., 2003: Behavioral responses of wildlife to human activity: terminology and methods. Wildlife Society Bulletin, 31: 1263-1271.

Tyler, N. J. C., 1986: Reinen i Adventdalen. In Øritsland, N. A. (ed.), Svalbardreinen og dens livsgrunnlag. Oslo: Universitetsforlaget, 143-159 (in Norwegian).

Tyler, N. J. C., and Øritsland, N. A., 1989: Why don't Svalbard reindeer migrate? Holarctic Ecology, 12: 369-376.

Van der Knaap, W. O., 1986: On the presence of reindeer (Rangifer tarandus L.) on Edgeøya, Spitzbergen in the period 3800-5000 BP. Circumpolar Journal, 2: 3-10.

Webb, J. K., Pike, D. A., and Shine, R., 2010: Olfactory recognition of predators by nocturnal lizards: safety outweighs thermal benefits. Behavioral Ecology, 21: 72-77.

Ydenberg, R. C., and Dill, L. M., 1986: The economics of fleeing from predators. Advanced Study Behaviour, 16: 229-249.

Zhang, X., and Walsh, J. E., 2006: Toward a seasonally ice-covered Arctic Ocean: scenarios from the IPCC AR4 model simulations. Journal of Climate, 19: 1730-1747. 


\section{Appendix}

TABLE A1

Flight behavior data from Svalbard reindeer (Rangifer tarandus platyrhynchus Vrolik, 1829) disturbed by a polar bear (Ursus maritimus Phipps, 1774), persons in polar bear disguise, and persons in dark hiking gear on Edgeøya, Svalbard, in 2006.

\begin{tabular}{|c|c|c|c|c|c|c|c|c|c|}
\hline Disturber & month & day & group size & group structure & encounter & sight & alert & flight & escape \\
\hline polar bear & 8 & 7 & 4 & mixed & 1500 & 400 & 300 & 300 & 350 \\
\hline disguise & 8 & 7 & 2 & males & 325 & 244 & 239 & 239 & 455 \\
\hline disguise & 8 & 7 & 2 & males & 480 & 250 & 243 & 243 & 395 \\
\hline disguise & 8 & 8 & 1 & male & 470 & 248 & 248 & 248 & 358 \\
\hline disguise & 8 & 8 & 2 & males & 1079 & 400 & 270 & 270 & 350 \\
\hline disguise & 8 & 8 & 4 & mixed & 1010 & 295 & 185 & 185 & 270 \\
\hline person & 7 & 26 & 1 & male & 334 & 313 & 232 & 47 & 460 \\
\hline person & 7 & 27 & 3 & mixed & 381 & 245 & 40 & 40 & 15 \\
\hline person & 7 & 27 & 3 & mixed & 420 & 375 & NA & NA & 450 \\
\hline person & 7 & 31 & 11 & mixed & 281 & 219 & 70 & 45 & 53 \\
\hline person & 7 & 31 & 2 & mixed & 432 & 114 & NA & NA & 123 \\
\hline person & 8 & 3 & 1 & male & 508 & 215 & 134 & 134 & 37 \\
\hline person & 7 & 29 & 1 & male & 381 & 313 & 253 & 141 & 105 \\
\hline person & 7 & 29 & 1 & male & 393 & 310 & 113 & 113 & 187 \\
\hline person & 7 & 29 & 1 & male & 424 & 313 & 170 & 128 & 154 \\
\hline person & 8 & 2 & 2 & males & 444 & 29 & 29 & 29 & 46 \\
\hline person & 8 & 6 & 2 & mixed & 119 & 119 & 119 & 119 & 85 \\
\hline
\end{tabular}

